\title{
MicroRNA Expression is Associated with Sepsis Disorders in Critically Ill Polytrauma Patients
}

\author{
Alexandru Florin Rogobete 1,2@D, Dorel Sandesc 1,2, Ovidiu Horea Bedreag 1,2, Marius Papurica 1,2, \\ Sonia Elena Popovici ${ }^{1}$, Tiberiu Bratu ${ }^{1}$, Calin Marius Popoiu ${ }^{1, *}$, Razvan Nitu ${ }^{1}$, Tiberiu Dragomir ${ }^{1}$, \\ Hazzaa I. M. AAbed ${ }^{1}$ and Mihaela Viviana Ivan ${ }^{1}$ \\ 1 Faculty of Medicine, “Victor Babes” University of Medicine and Pharmacy, 300041 Timisoara, Romania; \\ alexandru.rogobete@umft.ro (A.F.R.); dsandesc@yahoo.com (D.S.); bedreag.ovidiu@umft.ro (O.H.B.); \\ marius.papurica@umft.ro (M.P.); popovici.sonia@yahoo.com (S.E.P.); tiberiu.bratu@umft.ro (T.B.); \\ razvan.nitu@umft.ro (R.N.); tiberiu.dragomir@umft.ro (T.D.); hazzaa.aabed@gmail.com (H.I.M.A.); \\ viviana.ivan@umft.ro (M.V.I.) \\ 2 Clinic of Anesthesia and Intensive Care, Emergency County Hospital "Pius Brinzeu”, 300723 Timisoara, Romania \\ * Correspondence: mcpopoiu@yahoo.com; Tel.: +40-0729-101-221
}

Received: 2 November 2018; Accepted: 6 December 2018; Published: 13 December 2018

\begin{abstract}
A critically ill polytrauma patient is one of the most complex cases to be admitted to the intensive care unit, due to both the primary traumatic complications and the secondary post-traumatic interactions. From a molecular, genetic, and epigenetic point of view, numerous biochemical interactions are responsible for the deterioration of the clinical status of a patient, and increased mortality rates. From a molecular viewpoint, microRNAs are one of the most complex macromolecular systems due to the numerous modular reactions and interactions that they are involved in. Regarding the expression and activity of microRNAs in sepsis, their usefulness has reached new levels of significance. MicroRNAs can be used both as an early biomarker for sepsis, and as a therapeutic target because of their ability to block the complex reactions involved in the initiation, maintenance, and augmentation of the clinical status.
\end{abstract}

Keywords: microRNAs; epigenetic biomarker; sepsis; inflammation

\section{Introduction}

Critically ill polytrauma patients present one of the most complex clinical pictures that the intensivist and trauma team will encounter in their careers [1-5]. The complexity of these cases is due both to the initial traumatic injury, and to the secondary post-traumatic responses to injury [2-16]. Moreover, through the interactions of molecular mechanisms with other, initially functional systems, and through molecular denaturation reactions, the critically ill polytrauma patient becomes a complex medical case from a clinical and molecular point of view. A series of complex mechanisms involved in the pathophysiology and biochemistry of sepsis have been studied for the past several years. However, the critically ill polytrauma patient is so complex biochemically and molecularly that no specific biochemical pathways have been found in which intervention could increase survival rates, or decrease the incidence of sepsis and multiple organ dysfunction syndrome (MODS) [3-25]. However, in the last few years, a series of microRNA epigenetic species have been identified. These species are responsible for the modulation of certain complex molecular reactions. Furthermore, numerous studies have shown the importance of microRNAs in early diagnosis and possible future epigenetic therapies [6-33]. By examining microRNAs 
with respect to critically ill polytrauma patients, we can see important links between the development and modulation of the systemic inflammatory response, the immune system, coagulation status, and response to infections [7-22]. The paper aims to systematize the microRNA expressions that are closely related to the pathophysiological events involved in a critically ill polytrauma patient with sepsis. Moreover, we wished to highlight the most important microRNA expression studies conducted to date that could be used as biomarkers for the early diagnosis of sepsis.

\section{Biochemical and Biosynthesis Aspects of MicroRNAs}

From a molecular point of view, microRNAs are synthesized in the cell nucleus through the action of RNA polymerase II on certain specific genes. Hence, the initial species, the pri-microRNAs, are formed following complex reactions [13-35]. In the next step, RNAse III endonuclease, also called Drosha, activates the pri-microRNAs. This reaction is catalyzed by the DiGeorge Syndrome Critical Region 8 (DGCR8) complex, which leads to the formation of pre-microRNAs [15,34-74].

Once these almost final species are formed, the pre-microRNAs bind with the Exportin- 5 transporter protein, which shifts them from the nucleus into the cytoplasm. Inside the cytoplasm, a new reaction, initiated by an RNAse III endonuclease called Dicer and by the RNA binding protein (TRBP), takes place, which leads to the formation of the final microRNA species $[17,20,66-88]$. The last step involves coupling the RNA-induced silencing complex (RISC) [18,78-91]. The final molecular species is then transported outside the cell through different mechanisms and in various forms, such as ribonucleoprotein complexes, microvesicles, exosomes, and high-density lipoproteins (Figure 1) [14].

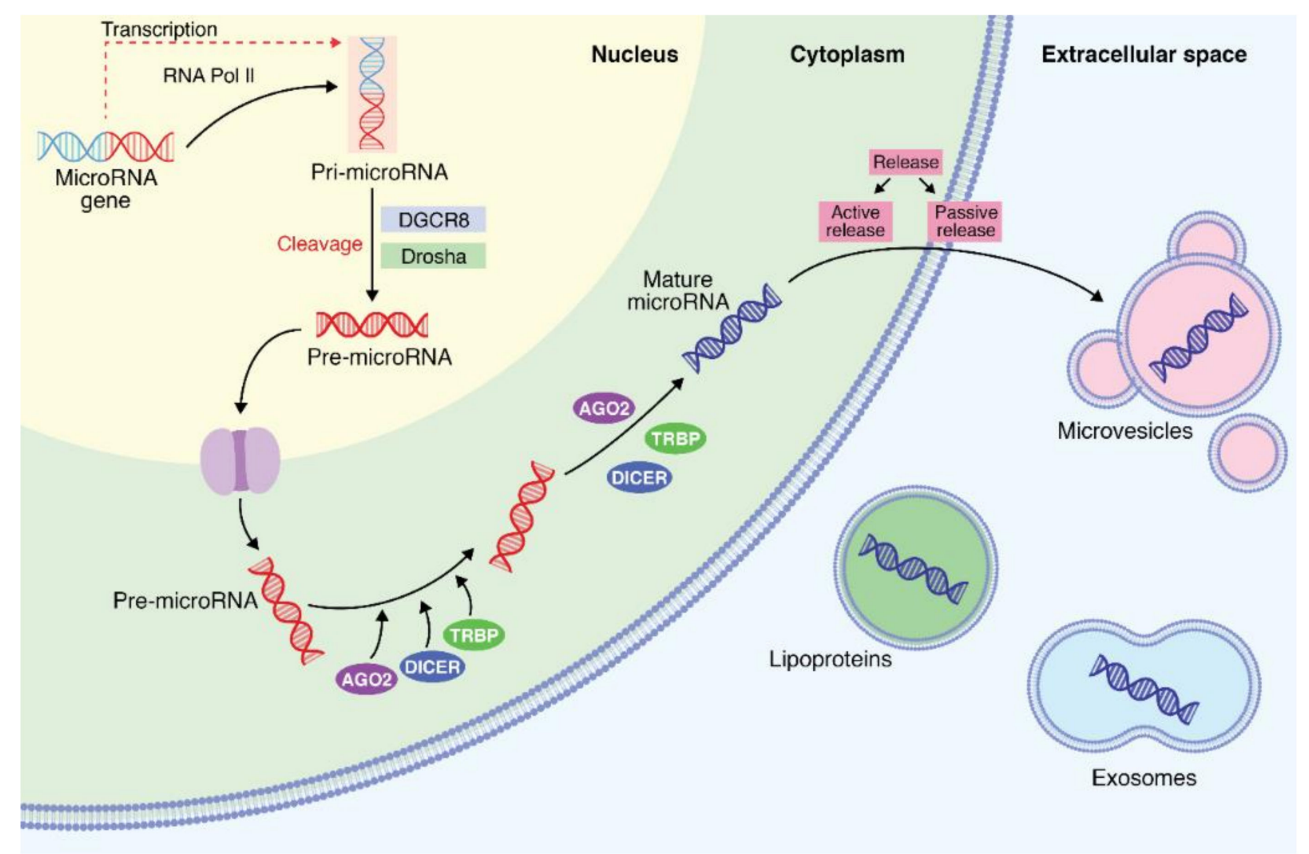

Figure 1. MicroRNA biosynthesis mechanisms. For further explanation, please see the details in the text. RNA pol II-RNA polymerase II; pri-microRNA—primitive microRNA; DGCR8—DiGeorge Syndrome Critical Region 8; Drosha-RNAse III endonuclease; pre-microRNA—precursor of microRNA; AGO2-endonuclease Argonaute 2; Dicer-Rnase III endonuclease; TRBP—transactivation response element RNA-binding protein. 


\section{MicroRNA Identification from Different Body Fluids}

MicroRNAs have been proposed as possible biomarkers because of the research evidence that shows that changes in a range of cellular microRNAs correlate with various pathophysiological conditions, including inflammation, oxidative stress, sepsis diabetes and different types of cancer [33-45,73-93]. These molecules have also been known for their low complexity, simple detection and amplification, tissue-restricted expression profiles, and sequence conservation between human and model organisms [9498]. However, they have not been incorporated into clinical practice due to several factors such as the lack of a universal and comprehensive measurement technique that would be convenient enough in terms of handling, the rate of analysis, and reliability [96-101]. Apart from the measurement technique, another factor that has been holding back the use of microRNAs is that their concentration in the body is relatively low. However, there exist measurement methods that have been routinely used, although they have their advantages and disadvantages. These techniques include small RNA sequencing, quantitative reverse transcription polymerase chain reaction (qPCR), and microarray hybridization. All of these are applied according to the respective propose of analysis (Figure 2). When it comes to the successful identification of these microRNAs, the factors that are critical, such as the choice of the measurement sample and the appropriate normalization strategy come into play. The profiles of these important biomarkers are also influenced considerably by exogenous factors such as medication, nutrition, and certain environmental conditions [98-114].

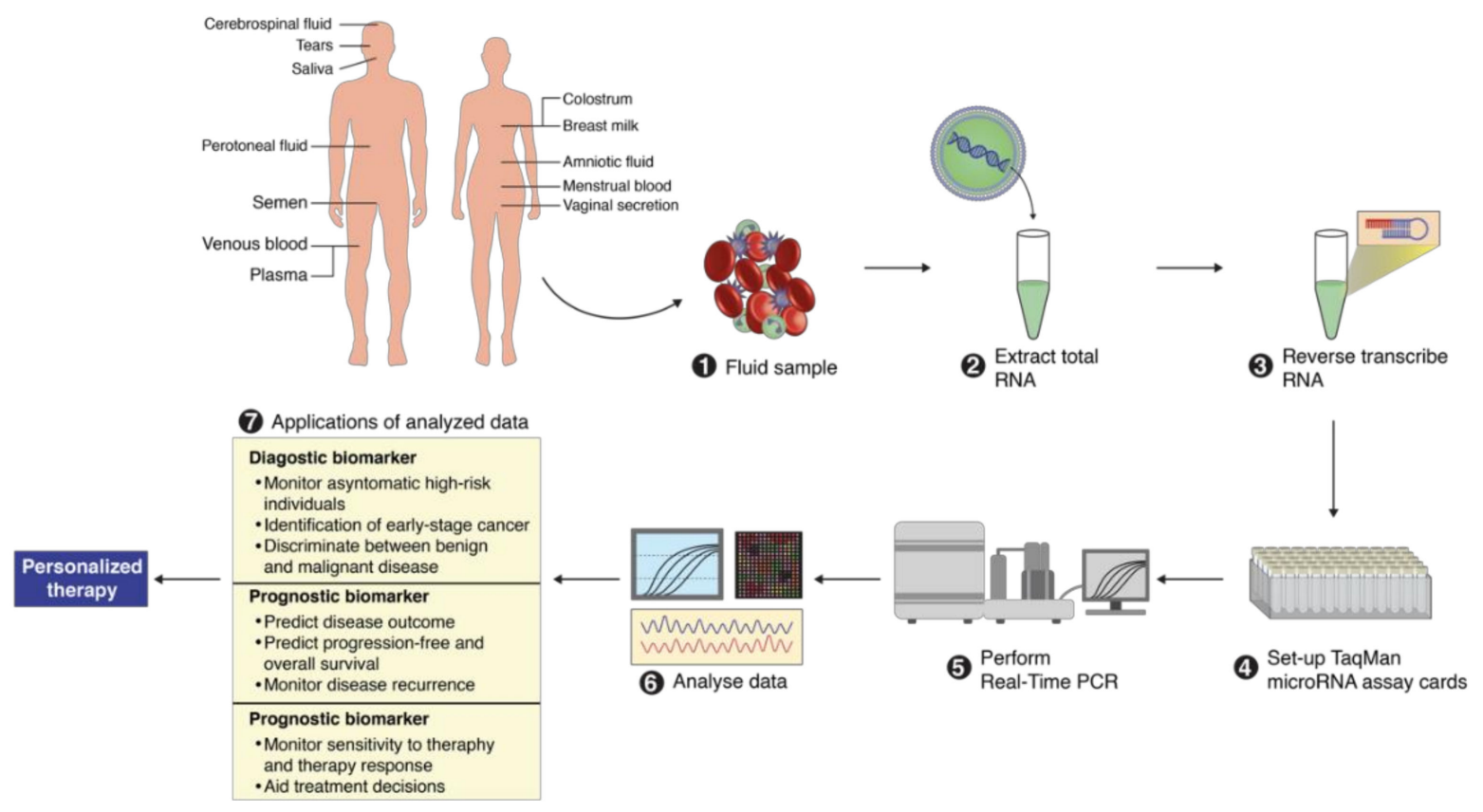

Figure 2. MicroRNA identification workflow from different body fluids.

\section{Importance of MicroRNAs for Clinical Use}

Due to their unique features, such as disease specificity, relative stability, and easy accessibility, microRNAs are considered the future biomarkers for the diagnosis and prognosis of specific diseases as well as monitoring therapeutic responses in clinical settings [75-79]. MicroRNAs have been identified in different clinical settings, and their importance as biomarkers is still under investigation [80-117]. For example, a number of these molecules have been associated with sepsis, acute lung injury and acute organ dysfunction diagnoses. MicroRNAs are also being considered for therapeutic purposes where 
up-regulatory or down-regulatory molecules, targeting specific microRNAs, can be administered with the aim of managing specific pathological conditions. A study of this is currently at the clinical trial stage. Studies have shown that the anesthetics and medications used in post-operative patient care affect the expression of microRNA, which in turn affects the functioning or survival of certain types of cells in the body, such as neurocytes. The expression of microRNAs in their various cells are highly specific, and therefore, they have a distinct display pattern in different tissues, which contributes to their characteristic features and functions. With this in mind, these molecules have been used to detect the presence of disease or tissue malfunction due to their recognizable pattern of appearance [97-105]. For instance, rough relations have been created linking specific microRNA expressions to the manifestation of certain pathological conditions, including microR-21 being shown as a proto-oncogene in adenocarcinoma, and microR-146a acting as an inhibitory factor to inflammatory processes by dampening the nuclear factor-kB (NF-kB) signaling [114-116]. MicroRNA has also been considered in forensic investigations due to their initially-named properties. It helps address the challenge of sensitivity and specificity when it comes to criminal identification. However, this is entirely dependent on the method applied in such endeavors. In criminal investigations, the disadvantages of microRNA profiling have not yet been studied [116,117].

\section{Roles of MicroRNAs in the Pathophysiology of Oxidative Stress Associated with Sepsis}

Under normal conditions, the human body synthesizes numerous biochemical species with increased reactivity compared to the existent macromolecules. These species are called free radicals and are divided depending on their origin into reactive oxygen species, reactive lipid species, reactive nitrogen species, and other more complex redox systems [20-74]. Biochemically speaking, the most aggressive free radicals are oxygen radicals such as hydroxyl radicals $\left(\mathrm{HO}^{-}\right)$, superoxide anions $\left(\mathrm{O}_{2}{ }^{-}\right)$, or hydrogen peroxide $\left(\mathrm{H}_{2} \mathrm{O}_{2}\right)$. Moreover, nitrogen radicals such as peroxynitrite $\left(\mathrm{ONOO}^{-}\right)$and nitric oxide $(\mathrm{NO})$, or the lipid radicals, especially the lipid peroxyl $\left(\mathrm{LOO}^{-}\right)$, also present similarly high reactivity $[3,19,20]$. The oxidative stress appears once the free radicals accumulate over the endogenous antioxidants. Under circumstances of traumatic stress, a series of endogenous systems are responsible for generating an excessive amount of free radicals. Among these, the most studied are mitochondrial respiration, the xanthine reduction mechanisms, and the NADPH oxidase enzymatic system [15,21-24]. Admittedly, under physiological conditions, the human body has a series of biomacromolecules with antioxidant capacities such as catalase (CAT) [25], superoxide dismutase (SOD) [26], peroxiredoxins (PRXs) [27], glutathione (GSH) [28], and glutaredoxins (GRXs). However, in the case of critically ill polytrauma patients, the production of free radicals overcomes the endogenous antioxidant capacity of the body, and therefore oxidative stress associated with the systemic inflammatory response appears very quickly. In the case of critically ill polytrauma patients, the pro-oxidative phenomenon appears at the moment of trauma because of the associated organic injuries. A short time after the traumatic impact, the molecular injury will be transmitted, augmented, and multiplied in the cell, especially inside the cellular organelles [29-31]. From a clinical point of view, the molecular lesions have important implications in the clinical evolution of a patient due to the significant increase in the morbidity and mortality rates through their association with the systemic inflammatory response, and also because of their association with generalized infections [32-36]. With regard to the association with infections, oxidative stress has significant implications in increasing the incidence of sepsis due to the release of free radicals, cytokines, and adhesion molecules. Hence, immunosuppression, the increased concentration of pro-inflammatory factors, and the aggressive attack of free radicals all lead to MODS in the critically ill polytrauma patient, despite complex treatment options (Figure 3) [37-85]. 


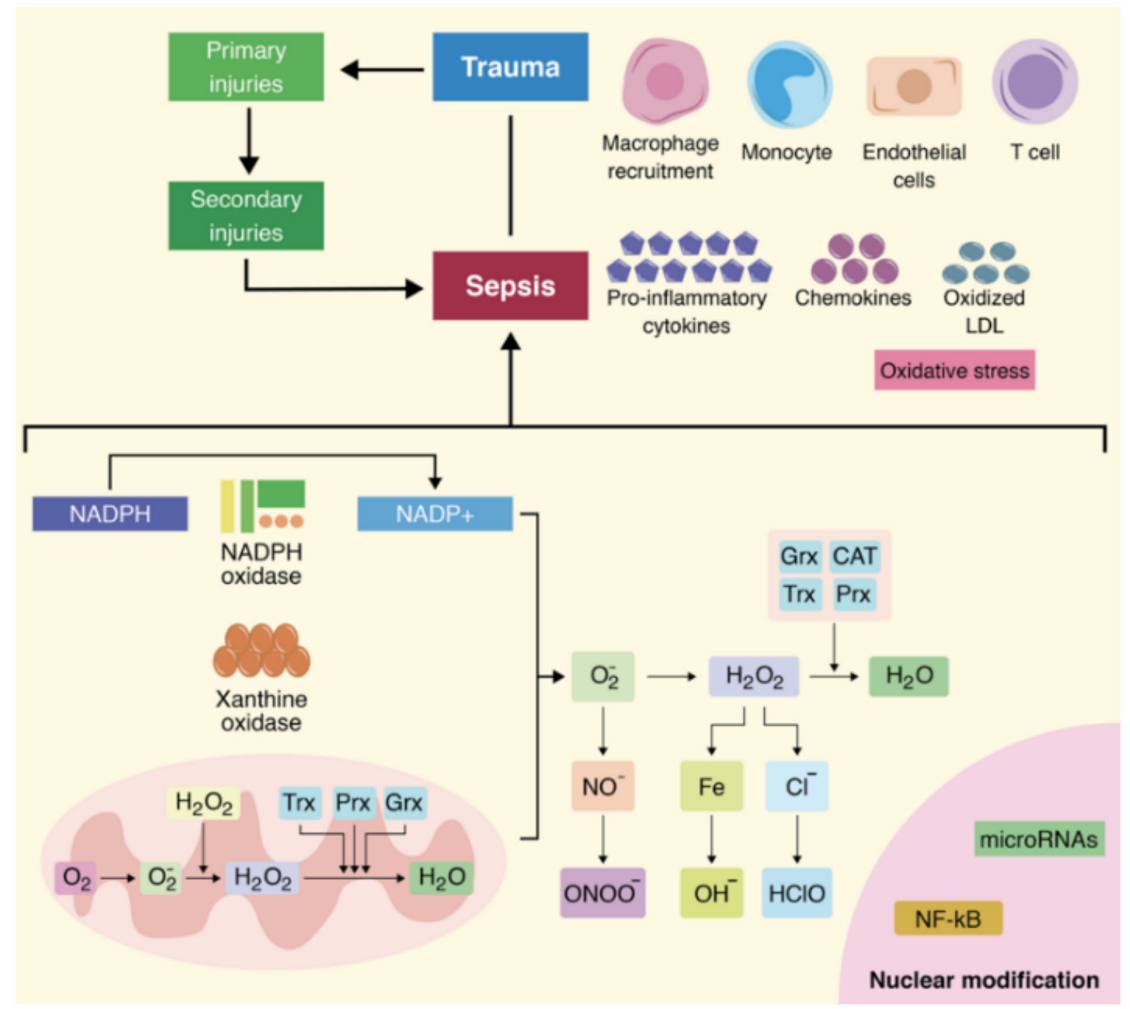

Figure 3. The critically ill polytrauma patient is characterized by a series of secondary, post-traumatic injuries, represented especially by cellular and molecular damage. Oxidative stress is an important molecular phenomenon, and it has important links with a series of bio-macromolecular systems. An important source of free radicals is the mitochondria, where huge amounts of free oxygen radicals are produced that will further lead to the augmentation of the pro-oxidative phenomena. Moreover, the molecular disaster will continue as other systems are affected such as the endovascular system, lipid molecules, proteins, and cellular organelles.

The microRNA species play an important role in the propagation of pro-oxidative signals by modifying the reactivity of the molecular receptors. Numerous studies have identified important implications of microRNAs for the cis-acting DNA sequences [41-43]. Practically, the cellular proliferation is influenced by microRNA-9 by modulating the activity of orphan nuclear receptor TLX, located in the neuroepithelium. Another example is the estrogen and androgen receptors that have microRNA-21, microRNA-222, microRNA-221, microRNA-101, microRNA-206, microRNA-433, microRNA-34a, microRNA-125b, and microRNA-127 as genetic substrates [44,45].

The nuclear transcription factor $\mathrm{kB}(\mathrm{NF}-\mathrm{kB})$ represents another interesting aspect of a molecular attack. From a biochemical viewpoint, NF-kB is involved in modifying the reactions of certain genes and is influenced in most cases by a series of external or internal factors such as the IKB and IKK proteins $[9,46,47]$. If we were to discuss the links between NF-kB and oxidative stress, and the implications of NF-kB in the clinical outcome of these patients, one could highlight the cellular adaptability induced by the pathophysiological changes arising from inflammation, infections, and the immune response. This can be explained through the implications that NF-kB has in the production of pro- and anti-inflammatory cytokines such as interleukin-1 (IL-1) and tumor necrosis factor-alpha (TNF-alpha) [48-51]. Moreover, in this complex series of events that make up a molecular disaster, there are numerous important links caused by the reciprocal activation of certain factors that are decisive in the augmentation of the molecular 
disaster. In the case of critically ill patients, a series of specific secondary phenomena occur, such as tissue hypoxia, generalized inflammation, and infections [52]. With regard to this, researchers have identified the microRNAs that play a decisive role in the modification of the biochemical pathways. An important study carried out by Scott et al. reported significant changes in the expression of microRNA-17-92, microRNA-221, microRNA-126, and microRNA-222 [53]. In the literature, other microRNA species that have important implications for endothelial damage have also been reported, such as microRNA-278 and microRNA-146 [54]. Another study carried out by Kung et al. reported reduced activity for microRNA-26a, microRNA-126, and microRNA-24 [55]. The same study showed increased expression of microRNA-346, microRNA-30b, microRNA-999, and microRNA-30a.

With regard to epigenetic expression in tissue hypoxia, microRNAs have been shown to have multiple implications, both augmenting cellular destruction and increasing the pro-inflammatory and pro-oxidative status [80-84]. Numerous microRNAs are responsible for dictating the biosynthesis for adhesion molecules, free oxygen, nitrogen, or lipid radicals, and affecting cell and mitochondria energy. Among these, the most microRNAs that have been most studied in-depth are microRNA-213, microRNA-210, microRNA-24, microRNA-27, microRNA-23, microRNA-26, microRNA-210-3p, microRNA 23b-3p, microRNA-1275, microRNA-210-3p, microRNA-145-5p, microRNA-92b-3p, microRNA-181a-2-3p, microRNA-185-5p, microrRNA-20a-5p, and microRNA-92b-3p [84-87]. Another associated phenomenon is ischemia-reperfusion syndrome. From a clinical and molecular point of view, ischemia-reperfusion is an important generator of free radicals and inflammatory molecules that are responsible for aggravating the clinical status of these patients, especially in the context of inflammation and infection. Important changes in epigenetic expression have also been identified in the case of ischemia-reperfusion syndrome. Among these, the most commonly studied are microRNA-290, microRNA-26, microRNA-192, microRNA-805, microRNA-194, microRNA-187, microRNA-145, and microRNA-21 [14,88,89].

A high proportion of critically ill polytrauma patients develop acute respiratory distress syndrome (ARDS). From a cellular and molecular viewpoint, in ARDS, the neutrophils invade the pulmonary tissue leading to the initiation of aggressive pro-inflammatory mechanisms $[48,56,70]$. The molecular cascade in this case is activated and augmented by the excess production of interleukin 6 (IL-6), interleukin 1 beta (IL-1), and tumor necrosis factor alpha (TNF-alpha). Furthermore, this molecular cascade leads to increased vascular permeability in the pulmonary tissue. The molecular reactions are extremely complex, with the inhibition of apoptosis in the alveolar capillaries through the action of vascular endothelial growth factor (VEGF) [60,71,72]. The VEGF receptors, including vascular endothelial growth factor receptor 1 (VEGFR1) and vascular endothelial growth factor receptor 2 (VEGFR2) are further activated, leading to increased vascular permeability. In this case, the expression of microRNAs also plays an important role, modulating a series of complex molecular reactions $[73,74]$. Yehya et al. reported important changes for microRNA-466c-5p, microRNA-466d-5p, microRNA-15b, microRNA-154, microRNA-466c, microRNA-466b, microRNA-466f-3p, microRNA-375, microRNA-378, microRNA-347, and microRNA-32* [75]. A similar study carried out on the same group of patients by Kulshreshtha et al. reported changes in the expressions of miRNA-27, miRNA-103, miRNA-107, miRNA-26, miRNA-181, miRNA-210, miRNA-23, miRNA-24, and miRNA-213 [76]. Likewise, important changes have been noted in these situations for miRNA-194, miRNA-214, miRNA-223, miRNA-100, miRNA-140, miRNA-142-3p, miRNA-25, miRNA-27b, miRNA-181c, miRNA-21, and microRNA-224 activity [77]. Tacke et al. reported an increased expression for microRNA-133a in patients with sepsis [78]. Wang et al. also reported the decreased expression of microRNA-223, microRNA-181b, and microRNA-146a [79] (Figure 4). 


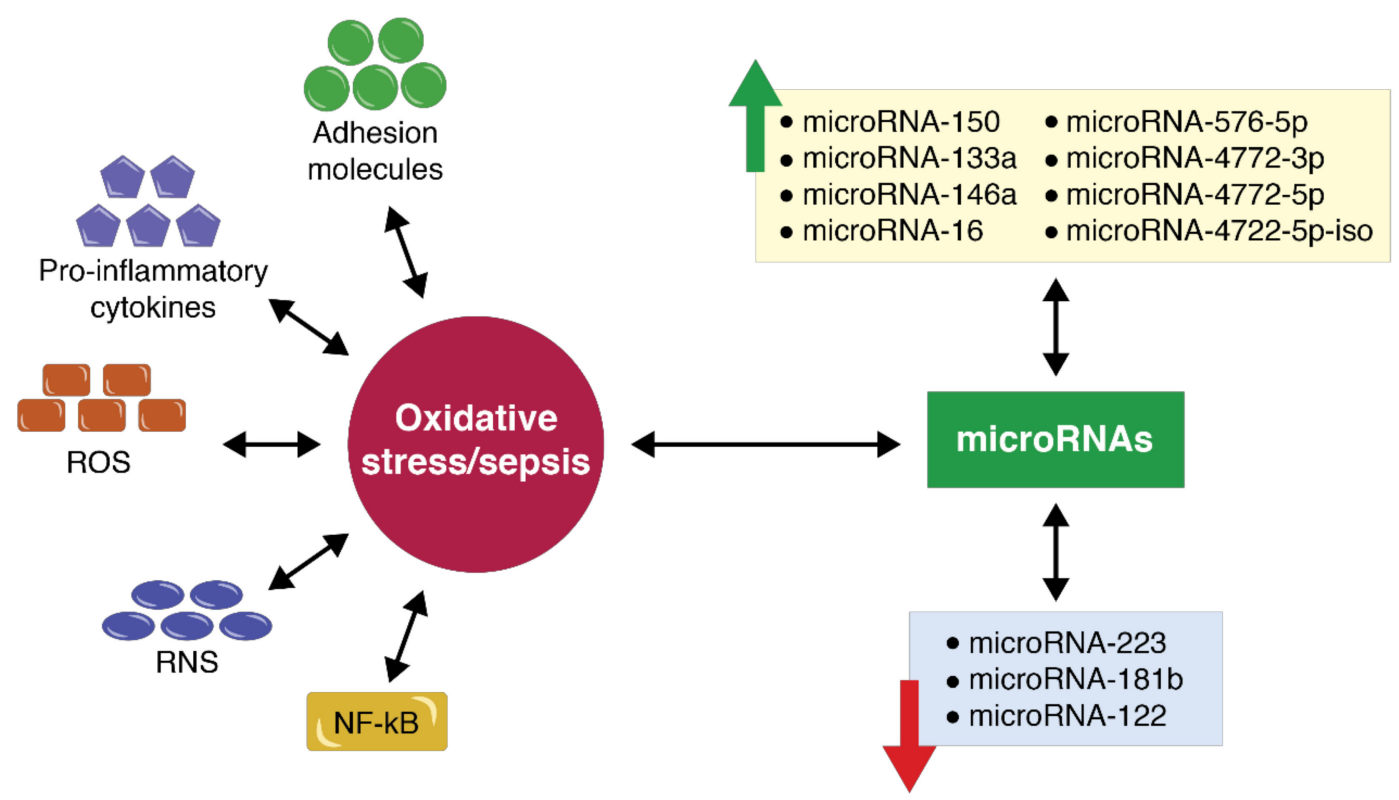

Figure 4. MicroRNA expression in a critically ill polytrauma patient with sepsis. A short time after the primary traumatic injury, the critically ill polytrauma patient develops a series of secondary post-traumatic injuries, especially molecular and cellular injuries. Among these, the most studied are the excess biosynthesis of free radicals reactive oxygen species (ROS) and reactive nitrogen species (RNS), and the augmentation of the pro-oxidative chain. Moreover, together with the involvement of the immune system, the activation of nuclear transcription factor kappa B (NF-kB), the emergence of adhesion molecules, the release of excess pro-inflammatory factors, and infections will determine a series of microRNA species that will intervene in the modulation of this complex molecular cycle. Numerous studies have shown both an increase in the activity of certain microRNA species, and a decrease in the expression of other species in certain selected cases [14,80-83].

Hyperoxia is closely related to ARDS. This phenomenon is mostly induced by the intensive care physician because of difficult ventilation and inadequate oxygen concentrations in the circulatory system. In these situations, the intensive care unit (ICU) Fi-inspired oxygen fraction $\left(\mathrm{FiO}_{2}\right)$ is usually increased to $1.0\left(100 \% \mathrm{O}_{2}\right)$. On the other hand, increasing $\mathrm{FiO}_{2}$ to 1.0 directly affects the mitochondria and the microvascular system. Together with the impairment of the microvascular system, the vascular perfusion in the pulmonary tissue will drop significantly, leading to a decreased gas-exchange capacity and the progressive deterioration of the patient's clinical status.

Vascular endothelial growth factor (VEGF) has been widely discussed in the literature in relation to microvascular injury. Specifically, a series of reactions involved in the inhibition of apoptosis in the alveolar capillaries has been mentioned in the literature. Moreover, an important increase in the expression of vascular endothelial growth factor receptor 1 (VEGFR1) in patients with ARDS has been demonstrated [58-60].

There are complex mechanisms that are closely related to the biofunctionality of the endothelial surface. An important system in this category is the KL-6 glycoprotein that can be found on the surface of type II alveolar cells [61]. From an immunological point of view, T-cell expression is widely influenced by all of these mechanisms. Recent studies have shown changes in the Foxp3+ regulatory T-cell (Tregs), CD4+, CD3+, CD25hi, CD127lo, and CD25+ expression [62]. 


\section{MicroRNA Expression in the Case of Polytrauma Patients with Sepsis}

From a pathophysiological and molecular viewpoint, in the case of polytrauma patients with sepsis, an important phenomenon appears due to excess cytokine synthesis. This is determined by the complex reactions between the lipopolysaccharide macromolecules (LPS) and lipopolysaccharide binding protein (LPB) $[63,64]$. The molecular bond required for these reactions to take place exists due to the CD14 receptor found on the surface of macrophages. Apart from these complex links, there are a series of other reactions represented especially by the synthesis of certain mediators, such as histamines, chemokines, or different hormones. Moreover, the coagulation cascade plays an important role in the augmentation and self-propagation of the molecular phenomena involved in sepsis. The most important pro-inflammatory and anti-inflammatory mediators are interleukin 4 (IL-4), interleukin 10 (IL-10), interleukin 17 (IL-17), interleukin 1 (IL-1), interleukin 2 (IL-2), interleukin 6 (IL-6), interleukin 12 (IL-12), interleukin 8 (IL-8), Procalcitonin (PCT), N-terminal C natriuretic peptide (NT-CNP), C-reactive proteins (CRP), tumor necrosis factor alpha (TNF-alpha), interferon gamma (INF-gamma), and transforming growth factor beta (TGF-beta) $[14,49,65,66]$.

Recent studies have shown a series of implications for microRNA species in the pathophysiology of sepsis, pro-inflammatory and pro-oxidative phenomena (Table 1). MicroRNA-146a, microRNA-150, and microRNA-233 have complex implications in the molecular damage in sepsis [67]. Moreover, Puskarich et al. reported strong statistical correlations between the changes in microRNA-150 expression and the increase in mortality rates. Another important study, carried out by Vasilescu et al. reported decreased activity for microRNA-150 and microRNA-342-5p in the case of septic patients. On the other hand, there was an increased expression of microRNA-486 and microRNA-182 in these patients [67]. A similar study carried out by Benz et al., identified important changes in microRNA-233 in patients with sepsis [68]. Other species involved in the molecular and genetic sepsis reactions include microRNA-340, microRNA-324-3p, microRNA-16, microRNA-210, let-7b, microRNA-15b, microRNA-484, microRNA-486-5p, and microRNA-324-3p [69].

Table 1. MicroRNA expression in sepsis.

\begin{tabular}{cccc}
\hline Involved MicroRNAs & Body Fluid of Identification & Expression & References \\
\hline microRNA-4772-5p & Serum & Up-regulated & {$[90-92]$} \\
microRNA-4772-5p Iso & Serum & Up-regulated & {$[92]$} \\
microRNA-15a & Serum & Up-regulated & {$[90,91]$} \\
microRNA-16 & Serum & Up-regulated & {$[90]$} \\
microRNA-574-5p & Serum & Up-regulated & {$[91]$} \\
microRNA-4772-3p & Serum & Up-regulated & {$[92]$} \\
microRNA-4516 & Serum & Up-regulated & {$[93]$} \\
microRNA-454-3p & Serum & Up-regulated & {$[93]$} \\
miR-155-3p & Serum & Up-regulated & {$[93]$} \\
microRNA-219b & Serum & Up-regulated & {$[94]$} \\
microRNA-1889 & Serum & Up-regulated & {$[94]$} \\
microRNA-106a & Serum & Up-regulated & {$[94]$} \\
microRNA-106b & Serum & Up-regulated & {$[94]$} \\
microRNA-205 & Serum & Up-regulated & {$[94]$} \\
microRNA-20a & Serum & Up-regulated & {$[94]$} \\
miR-150 & Serum & Up-regulated & {$[91]$} \\
microRNA-27a & Serum & Up-regulated & {$[95]$} \\
microRNA-122 & Serum & Up-regulated & {$[96]$} \\
microRNA-146a & Serum & Up-regulated & {$[91]$} \\
microRNA-422 & Serum & & {$[91]$} \\
\hline
\end{tabular}


Table 1. Cont.

\begin{tabular}{cccc}
\hline Involved MicroRNAs & Body Fluid of Identification & Expression & References \\
\hline microRNA-133a & Serum & Up-regulated & {$[90-95]$} \\
microRNA-4532 & Serum & Up-regulated & {$[95]$} \\
microRNA-576-5p & Serum & Up-regulated & {$[80-83]$} \\
microRNA-483-5p & Serum & Down-regulated & {$[91]$} \\
microRNA-499-5p & Serum & Down-regulated & {$[91]$} \\
microRNA-193b* & Serum & Down-regulated & {$[91]$} \\
miR-146a-5p & Serum & Down-regulated & {$[93]$} \\
Let-7g-5p & Serum & Down-regulated & {$[93]$} \\
microRNA-30 & Serum & Down-regulated & {$[94]$} \\
microRNA-199a-3p & Serum & Down-regulated & {$[93]$} \\
microRNA-29 & Serum & Down-regulated & {$[95,96]$} \\
microRNA-297 & Serum & Down-regulated & {$[96]$} \\
microRNA-125 & Serum & Down-regulated & {$[96]$} \\
microRNA-25 & Serum & Down-regulated & {$[96]$} \\
microRNA-19 & Serum & Down-regulated & {$[95]$} \\
microRNA-182 & Blood & Up-regulated & {$[95,96]$} \\
microRNA-15b & Blood & Up-regulated & {$[95]$} \\
microRNA-486 & Blood & Up-regulated & {$[94-96]$} \\
microRNA-25 & Blood & Down-regulated & {$[90]$} \\
microRNA-223 & Blood & Down-regulated & {$[92-95]$} \\
microRNA-181b & Blood & Down-regulated & {$[90]$} \\
microRNA-342-5p & Blood & Down-regulated & {$[94,95]$} \\
microRNA-126 & Blood & Down-regulated & {$[90]$} \\
microRNA-499-5p & Blood & Down-regulated & {$[90]$} \\
\hline
\end{tabular}

Moreover, numerous studies have reported a series of microRNAs that did not show significant changes regarding their expression in sepsis. Such microRNA species have been identified both in the patients' serum (microRNA-451, [95], microRNA-494 [90]), as well as in the plasma (let-7i [90]) and blood (microRNA-21, microRNA-503, microRNA-155, microRNA-486-5p, microRNA-132, microRNA-203, and microRNA-1249 [90-95]) (Table 2).

Table 2. MicroRNA expression unchanged in sepsis.

\begin{tabular}{cccc}
\hline Involved MicroRNAs & Body Fluid of Identification & Expression & References \\
\hline microRNA-451 & Serum & Unchanged & {$[95]$} \\
microRNA-494 & Serum & Unchanged & {$[90]$} \\
Let-7i & Plasma & Unchanged & {$[90]$} \\
microRNA-21 & Blood & Unchanged & {$[90]$} \\
microRNA-503 & Blood & Unchanged & {$[90]$} \\
microRNA-155 & Blood & Unchanged & {$[91]$} \\
microRNA-486-5p & Blood & Unchanged & {$[95]$} \\
microRNA-132 & Blood & Unchanged & {$[95]$} \\
microRNA-203 & Blood & Unchanged & {$[90]$} \\
microRNA-1249 & Blood & Unchanged & {$[90]$} \\
\hline
\end{tabular}

\section{Conclusions}

The complexity of the pathophysiological and molecular mechanisms in critically ill polytrauma patients is very high. They are responsible for the worsening of the patient's clinical status under certain circumstances. Understanding and preventing certain biomolecular and epigenetic mechanisms could lead to decreased molecular and cellular injury, as well as a lower overall risk for these patients. MicroRNA 
expression is a strong candidate for the future of intensive care because of the early diagnosis opportunity and because of its capacity to interact with certain key points of the biochemical pathways. Among these, the most widely-studied species are represented by microRNA-150, microRNA-133a, microRNA-146a, microRNA-576-5p, microRNA-4772-3p, microRNA4772-5p, and microRNA4722-5p-iso- the expression of which is highly augmented-as well as microRNA-223, microRNA-181b, and microRNA-122, which have lower levels in sepsis patients. Moreover, these microRNA species can be determined in different body fluids, such as serum, plasma, and blood, widening the range of options for the epigenetic determination of sepsis in critically ill polytrauma patients. However, until now, the epigenetic interactions in a clinical context have not been clearly reported, and further studies are necessary to identify the correct context for microRNA expression.

Author Contributions: Conceptualization, A.F.R. and D.S.; methodology, O.H.B. and M.P.; software, S.E.P.; validation, D.S., T.B., M.V.I. and A.F.R.; formal analysis, R.N.; investigation, C.M.P.; resources, T.D.; data curation, A.F.R.; writing-original draft preparation, A.F.R.; writing-review and editing, S.E.P.; visualization, D.S.; supervision, D.S.; project administration, T.B.; funding acquisition, O.H.B. and H.I.M.A.

Funding: This research received no external funding.

Acknowledgments: This article was published with the help from the "Aurel Mogoseanu" Association for Anesthesia and Intensive Care, Timisoara, Romania. The authors wish to thank the Clinical Research Network Company for their support during the completion of this paper.

Conflicts of Interest: The authors declare no conflict of interest.

\section{References}

1. Rogobete, A.F.; Sandesc, D.; Papurica, M.; Stoicescu, E.R.; Popovici, S.E.; Bratu, L.M.; Vernic, C.; Sas, A.M.; Stan, A.T.; Bedreag, O.H. The influence of metabolic imbalances and oxidative stress on the outcome of critically ill polytrauma patients: A review. Burn Trauma 2017, 5, 8. [CrossRef] [PubMed]

2. Papurica, M.; Rogobete, A.F.; Sandesc, D.; Cradigati, C.A.; Sarandan, M.; Dumache, R.; Horhat, F.G.; Bratu, L.M.; Nitu, R.; Crisan, D.C.; et al. Using the expression of damage-associated molecular pattern (DAMP) for the evaluation and monitoring of the critically Ill polytrauma patient. Clin. Lab. 2016, 62, 1829-1840. [CrossRef] [PubMed]

3. Horhat, F.G.; Rogobete, A.F.; Papurica, M.; Sandesc, D.; Tanasescu, S.; Dumitrascu, V.; Licker, M.; Nitu, R.; Cradigati, C.A.; Sarandan, M.; et al. The use of lipid peroxidation expression as a biomarker for the molecular damage in the critically Ill polytrauma patient. Clin. Lab. 2016, 62, 1601-1607. [CrossRef] [PubMed]

4. Berger, M.M.; Soguel, L.; Shenkin, A.; Revelly, J.-P.; Pinget, C.; Baines, M.; Chioléro, R.L. Influence of early antioxidant supplements on clinical evolution and organ function in critically ill cardiac surgery, major trauma, and subarachnoid hemorrhage patients. Crit. Care 2008, 12, R101. [CrossRef] [PubMed]

5. Papurica, M.; Rogobete, A.F.; Sandesc, D.; Dumache, R.; Nartita, R.; Sarandan, M.; Cradigati, A.C.; Luca, L.; Vernic, C.; Bedreag, O.H. Redox changes induced by general anesthesia in critically Ill patients with multiple traumas. Mol. Biol. Int. 2015, 2015. [CrossRef]

6. Ning, B.; Gao, L.; Liu, R.; Liu, Y.; Zhang, N.; Chen, Z. MicroRNAs in spinal cord injury: Potential roles and therapeutic implications. Int. J. Biol. Sci. 2014, 10, 997-1006. [CrossRef]

7. Dumache, R.; Ciocan, V.; Muresan, C.; Rogobete, A.F.; Enache, A. Circulating microRNAs as promising biomarkers in forensic body fluids identification. Clin. Lab. 2015, 61, 1129-1135. [CrossRef] [PubMed]

8. Saugstad, J.A. MicroRNAs as effectors of brain function with roles in ischemia and injury, neuroprotection, and neurodegeneration. J. Cereb. Blood Flow Metab. 2010, 30, 1564-1576. [CrossRef] [PubMed]

9. Papurica, M.; Rogobete, A.F.; Sandesc, D.; Cradigati, C.A.; Sarandan, M.; Crisan, D.C.; Horhat, F.G.; Boruga, O.; Dumache, R.; Nilima, K.R.; et al. The expression of nuclear transcription factor kappa B (NF- $\mathrm{kB}$ ) in the case of critically Ill polytrauma patients with sepsis and its interactions with microRNAs. Biochem. Genet. 2016, 54, 337-347. [CrossRef] 
10. Bedreag, O.H.; Rogobete, A.F.; Sandesc, D.; Cradigati, C.A.; Sarandan, M.; Popovici, S.E.; Dumache, R.; Horhat, F.G.; Vernic, C.; Sima, L.V.; et al. Modulation of the redox expression and inflammation response in the crtically Ill polytrauma patient with thoracic injury. Statistical correlations between antioxidant therapy and clinical aspects. A retrospective single center study. Clin. Lab. 2016, 62, 1747-1759. [CrossRef]

11. Chandrasekaran, S.; Bonchev, D. Network topology analysis of post-mortem brain microarrays identifies more Alzheimer's related genes and microRNAs and points to novel routes for fighting with the disease. PLoS ONE 2016, 11, e0144052. [CrossRef] [PubMed]

12. Halvorsen, A.R.; Bjaanæs, M.; Leblanc, M.; Holm, A.M.; Rubio, L.; Peñalver, J.C.; Cervera, J.; Mojarrieta, J.C.; Bolstad, N.; Lopez-Guerrero, J.A.; et al. A unique set of 6 circulating microRNAs for early detection of non-small cell lung cancer. Oncotarget 2016, 7, 37250-37259. [CrossRef] [PubMed]

13. David, L.V.; Ercisli, M.F.; Rogobete, A.F.; Boia, E.S.; Horhat, R.; Nitu, R.; Diaconu, M.M.; Pirtea, L.; Ciuca, I.; Horhat, D.; et al. Early prediction of sepsis incidence in critically Ill patients using specific genetic polymorphisms. Biochem. Genet. 2017, 55, 193-203. [CrossRef] [PubMed]

14. Essandoh, K.; Fan, G.C. Role of extracellular and intracellular microRNAs in sepsis. Biochim. Biophys. Acta 2014, 1842, 2155-2162. [CrossRef] [PubMed]

15. MacFarlane, L.A.; Murphy, P.R. MicroRNA: Biogenesis, function and role in cancer. Curr. Genom. 2010, 11, 537-561. [CrossRef] [PubMed]

16. Bratu, L.M.; Rogobete, A.F.; Papurica, M.; Sandesc, D.; Cradigati, C.A.; Sarandan, M.; Dumache, R.; Popovici, S.E.; Crisan, D.C.; Stanca, H.; et al. Literature research regarding miRNAs' expression in the assessment and evaluation of the critically Ill polytrauma patient with traumatic brain and spinal cord injury. Clin. Lab. 2016, 62, 2019-2024. [CrossRef] [PubMed]

17. Macias, S.; Michlewski, G.; Cáceres, J.F. Hormonal regulation of microRNA biogenesis. Mol. Cell 2009, 36, 172-173. [CrossRef]

18. Bedreag, O.H.; Papurica, M.; Rogobete, A.F.; Sandesc, D.; Dumache, R.; Cradigati, C.A.; Sarandan, M.; Bratu, L.M.; Popovici, S.E.; Sima, L.V. Using circulating miRNAs as biomarkers for the evaluation and monitoring of the mitochondrial damage in the critically Ill polytrauma patients. Clin. Lab. 2016, 62, 1397-1403. [CrossRef]

19. Bedreag, O.H.; Sandesc, D.; Chiriac, S.D.; Rogobete, A.F.; Cradigati, A.C.; Sarandan, M.; Dumache, R.; Nartita, R.; Papurica, M. The use of circulating miRNAs as biomarkers for oxidative stress in critically Ill polytrauma patients. Clin. Lab. 2016, 62, 263-274. [CrossRef]

20. Bedreag, O.H.; Rogobete, A.F.; Sarandan, M.; Cradigati, A.C.; Papurica, M.; Dumbuleu, M.C.; Chira, A.M.; Rosu, O.M.; Sandesc, D. Oxidative stress in severe pulmonary trauma in critical ill patients. Antioxidant therapy in patients with multiple trauma-A review. Anaesthesiol. Intens. Ther. 2015, 47, 351-359. [CrossRef]

21. Ticlea, M.; Bratu, L.M.; Bodog, F.; Bedreag, O.H.; Rogobete, A.F.; Crainiceanu, Z.P. The use of exosomes as biomarkers for evaluating and monitoring critically Ill polytrauma patients with sepsis. Biochem. Genet. 2017, 55, 1-9. [CrossRef] [PubMed]

22. Sandesc, M.; Dinu, A.; Rogobete, A.F.; Bedreag, O.H.; Sandesc, D.; Papurica, M.; Bratu, L.M.; Negoita, S.; Vernic, C.; Popovici, S.E.; et al. Circulating microRNAs expressions as genetic biomarkers in pancreatic cancer patients continuous non-invasive monitoring. Clin. Lab. 2017, 63, 1561-1566. [CrossRef] [PubMed]

23. Negoita, S.I.; Sandesc, D.; Rogobete, A.F.; Dutu, M.; Bedreag, O.H.; Papurica, M.; Ercisli, M.F.; Popovici, S.E.; Dumache, R.; Sandesc, M.; et al. MiRNAs expressions and interaction with biological systems in patients with Alzheimer's disease. Using miRNAs as a diagnosis and prognosis biomarker. Clin. Lab. 2017, 63, $1315-1321$. [CrossRef] [PubMed]

24. Etheridge, A.; Lee, I.; Hood, L.; Galas, D.; Wang, K. Extracellular microRNA: A new source of biomarkers. Mutat. Res. Fundam. Mol. Mech. Mutagen. 2011, 717, 85-90. [CrossRef] [PubMed]

25. Guerra, R.C.; Zuñiga-muñoz, A.; Lans, V.G.; Díaz-díaz, E.; Alberto, C.; Betancourt, T.; Pérez-torres, I. Modulation of the activities of catalase, $\mathrm{Cu}-\mathrm{Zn}, \mathrm{Mn}$ superoxide dismutase, and glutathione peroxidase in adipocyte from ovariectomised female rats with metabolic syndrome. Int. J. Endocrinol. 2014, 2014. [CrossRef] [PubMed] 
26. Arcaroli, J.J.; Hokanson, J.E.; Abraham, E.; Geraci, M.; Murphy, J.R.; Bowler, R.P.; Dinarello, C.A.; Silveira, L.; Sankoff, J.; Heyland, D.; et al. Extracellular superoxide dismutase haplotypes are associated with acute lung injury and mortality. Am. J. Respir. Crit. Care Med. 2009, 179, 105-112. [CrossRef] [PubMed]

27. Horhat, F.G.; Gundogdu, F.; David, L.V.; Boia, E.S.; Pirtea, L.; Horhat, R.; Cucui-Cozma, A.; Ciuca, I.; Diaconu, M.; Nitu, R.; et al. Early evaluation and monitoring of critical patients with acute respiratory distress syndrome (ARDS) using specific genetic polymorphisms. Biochem. Genet. 2017, 55, 204-211. [CrossRef] [PubMed]

28. Schmitt, B.; Vicenzi, M.; Garrel, C.; Denis, F.M. Redox biology effects of N-acetylcysteine, oral glutathione (GSH) and a novel sublingual form of GSH on oxidative stress markers: A comparative crossover study. Redox Biol. 2015, 6, 198-205. [CrossRef]

29. Hwang, J.H.; Ryu, J.; An, J.N.; Kim, C.T.; Kim, H.; Yang, J.; Ha, J.; Chae, D.W.; Ahn, C.; Jung, I.M.; et al. Pretransplant malnutrition, inflammation, and atherosclerosis affect cardiovascular outcomes after kidney transplantation. BMC Nephrol. 2015, 16, 109. [CrossRef]

30. Yin, G.; Wang, Y.; Cen, X.; Yang, M.; Liang, Y.; Xie, Q. Lipid peroxidation-mediated inflammation promotes cell apoptosis through activation of NF-kB pathway in rheumatoid arthritis synovial cells. Mediat. Inflamm. 2015, 2015, 460310. [CrossRef]

31. Sies, H. Oxidative stress: A concept in redox biology and medicine. Redox Biol. 2015, 4, 180-183. [CrossRef] [PubMed]

32. Tavladaki, T.; Spanaki, A.; Dimitriou, H.; Kozlov, A.; Duvigneau, J.; Weidinger, A.; Kondili, E.; Georgopoulos, D.; Briassoulis, G. Bioenergetics and metabolic patterns in early onset severe sepsis or trauma. Intensiv. Care Med. Exp. 2015, 3, A43. [CrossRef]

33. Denk, S.; Perl, M.; Huber-Lang, M. Damage- and pathogen-associated molecular patterns and alarmins: Keys to sepsis? Eur. Surg. Res. 2012, 48, 171-179. [CrossRef] [PubMed]

34. Soud, D.E.M.; Amin, O.A.I.; Amin, A.A.I. New era "soluble triggering receptor expressed on myeloid cells-I" as a marker for early detection of infection in trauma patients. Egypt. J. Anaesth. 2011, 27, 267-272. [CrossRef]

35. Horton, J.W. Free radicals and lipid peroxidation mediated injury in burn trauma: The role of antioxidant therapy. Toxicology 2003, 189, 75-88. [CrossRef]

36. Van der Kuip, M.; De Meer, K.; Oosterveld, M.J.S.; Lafeber, H.N.; Gemke, R.J.B.J. Simple and accurate assessment of energy expenditure in ventilated paediatric intensive care patients. Clin. Nutr. 2004, 23, 657-663. [CrossRef]

37. Andruszkow, H.; Fischer, J.; Sasse, M.; Brunnemer, U.; Andruszkow, J.H.K.; Gänsslen, A.; Hildebrand, F.; Frink, M. Interleukin-6 as inflammatory marker referring to multiple organ dysfunction syndrome in severely injured children. Scand. J. Trauma Resusc. Emerg. Med. 2014, 22, 16. [CrossRef]

38. Gu, W.; Jiang, J. Genetic polymorphisms and posttraumatic complications. Comp. Funct. Genom. 2010, 2010. [CrossRef]

39. Burkhardt, M.; Nienaber, U.; Pizanis, A.; Maegele, M.; Culemann, U.; Bouillon, B.; Flohé, S.; Pohlemann, T.; Paffrath, T. Acute management and outcome of multiple trauma patients with pelvic disruptions. Crit. Care 2012, 16, R163. [CrossRef]

40. Gao, J.; Zeng, L.; Zhang, A.; Wang, X.; Pan, W.; Du, D. Identification of haplotype tag single-nucleotide polymorphisms within the PPAR family genes and their clinical relevance in patients with major trauma. Int. J. Environ. Res. Public Health 2016, 13, 374. [CrossRef]

41. Zhao, C.; Sun, G.Q.; Ye, P.; Li, S.; Shia, Y. MicroRNA let-7d regulates the TLX/microRNA-9 cascade to control neural cell fate and neurogenesis. Sci. Rep. 2013, 3, 1329. [CrossRef] [PubMed]

42. Ramachandran, S.; Coffin, S.L.; Tang, T.Y.; Jobaliya, C.D.; Spengler, R.M.; Davidson, B.L. Cis-acting single nucleotide polymorphisms alter microRNA-mediated regulation of human brain-expressed transcripts. Hum. Mol. Genet. 2016, 25, 4939-4950. [CrossRef]

43. Yuva-Aydemir, Y.; Simkin, A.; Gascon, E.; Gao, F.B. MicroRNA-9—Functional evolution of a conserved small regulatory RNA. RNA Biol. 2011, 8, 557-564. [CrossRef] [PubMed]

44. Klinge, C.M. Estrogen regulation of microRNA expression. Curr. Genom. 2009, 10, 169-183. [CrossRef] [PubMed]

45. Fibach, E.; Dana, M. Oxidative stress in paroxysmal nocturnal hemoglobinuria and other conditions of complement-mediated hemolysis. Free Radic. Biol. Med. 2015, 88, 63-69. [CrossRef] 
46. Abraham, E. Nuclear factor-kB and its role in sepsis-associated organ failure. J. Infect. Dis. 2003, 187, S364-S369. [CrossRef]

47. Bernardes, M.; Vieira, T.S.; Martins, M.J.; Lucas, R.; Costa, L.; Pereira, J.G.; Ventura, F.; Martins, E. Myocardial perfusion in rheumatoid arthritis patients: Associations with traditional risk factors and novel biomarkers. Biomed. Res. Int. 2017, 2017. [CrossRef]

48. Salsano, E.; Rizzo, A.; Bedini, G.; Bernard, L.; Olio, V.D.; Volorio, S.; Lazzaroni, M.; Ceccherini, I.; Lazarevic, D.; Cittaro, D.; et al. An autoinflammatory neurological disease due to interleukin 6 hypersecretion. J. Neuroinflamm. 2013, 10, 802. [CrossRef]

49. Treszl, A.; Kocsis, I.; Szathmári, M.; Schuler, Á.; Héninger, E.; Tulassay, T.; Vásárhelyi, B. Genetic variants of TNF- $\alpha$, IL-1 $\beta$, IL-4 receptor $\alpha$-Chain, IL-6 and IL-10 genes are not risk factors for sepsis in low-birth-weight infants. Neonatology 2003, 83, 241-245. [CrossRef]

50. Harding, D.; Dhamrait, S.; Millar, A.; Humphries, S.; Marlow, N.; Whitelaw, A.; Montgomery, H. Is interleukin-6-174 genotype associated with the development of septicemia in preterm infants? Pediatrics 2003, 112, 800-803. [CrossRef]

51. Chuang, T.-Y.; Chang, H.-T.; Chung, K.-P.; Cheng, H.-S.; Liu, C.-Y.; Liu, Y.-C.; Huang, H.-H.; Chou, T.-C.; Chang, B.-L.; Lee, M.-R.; et al. High levels of serum macrophage migration inhibitory factor and interleukin 10 are associated with a rapidly fatal outcome in patients with severe sepsis. Int. J. Infect. Dis. 2014, 20, 13-17. [CrossRef] [PubMed]

52. Bedreag, O.H.; Rogobete, A.F.; Cradigati, C.A.; Sarandan, M.; Nartita, R.; Horhat, F.G.; Popovici, S.E.; Sandesc, D.; Papurica, M. A novel evaluation of microvascular damage in critically ill polytrauma patients by using circulating micrornas. Rev. Rom. Med. Lab. 2016, 24, 21-30. [CrossRef]

53. Scott, E.; Loya, K.; Mountford, J.; Milligan, G.; Baker, A.H. MicroRNA regulation of endothelial homeostasis and commitment-Implications for vascular regeneration strategies using stem cell therapies. Free Radic. Biol. Med. 2013, 64, 52-60. [CrossRef] [PubMed]

54. Hulsmans, M.; Holvoet, P. MicroRNA-containing microvesicles regulating inflammation in association with atherosclerotic disease. Cardiovasc. Res. 2013, 100, 7-18. [CrossRef] [PubMed]

55. Kung, C.; Hsiao, S.; Tsai, T.; Su, C.; Chang, W.; Huang, C.; Wang, H.; Lin, W.; Chang, H.; Lin, Y.; et al. Plasma nuclear and mitochondrial DNA levels as predictors of outcome in severe sepsis patients in the emergency room. J. Transl. Med. 2012, 10, 130. [CrossRef] [PubMed]

56. Haas, C. Lung protective mechanical ventilation in acute respiratory distress syndrome. Respir. Care Clin. 2003, 9, 363-396. [CrossRef]

57. Haas, S.; Trepte, C. Prediction of volume responsiveness using pleth variability index in patients undergoing cardiac surgery after cardiopulmonary bypass. J. Anesth. 2012, 26, 696-701. [CrossRef] [PubMed]

58. Wada, T.; Jesmin, S.; Gando, S.; Yanagida, Y.; Mizugaki, A.; Sultana, S.N.; Zaedi, S. The role of angiogenic factors and their soluble receptors in acute lung injury (ALI)/acute respiratory distress syndrome (ARDS) associated with critical illness. J. Inflamm. 2013, 10, 6. [CrossRef]

59. Medford, A.R.L.; Godinho, S.I.H.; Keen, L.J. Fluid vascular endothelial growth factor protein levels in patients with and at risk for ARDS. Chest 2009, 136, 457-464. [CrossRef]

60. Abadie, Y.; Bregeon, F.; Papazian, L.; Lange, F.; Thomas, P.; Duvaldestin, P.; Adnot, S. Decreased VEGF concentration in lung tissue and vascular injury during ARDS. Eur. Respir. J. 2005, 25, 139-146. [CrossRef]

61. Kondo, T.; Hattori, N.; Ishikawa, N.; Murai, H.; Haruta, Y.; Hirohashi, N.; Tanigawa, K.; Kohno, N. KL-6 concentration in pulmonary epithelial lining fluid is a useful prognostic indicator in patients with acute respiratory distress syndrome. Respir. Res. 2011, 12, 32. [CrossRef] [PubMed]

62. Aggarwal, N.R.; Alessio, F.R.D.; Tsushima, K.; Sidhaye, V.K.; Cheadle, C.; Grigoryev, D.N.; Barnes, K.C.; King, L.S. Regulatory $\mathrm{T}$ cell-mediated resolution of lung injury: Identification of potential target genes via expression profiling. Physiol. Genom. 2010, 41, 109-119. [CrossRef] [PubMed]

63. Pena, O.M.; Hancock, D.G.; Lyle, N.H.; Linder, A.; Russell, J.A.; Xia, J.; Fjell, C.D.; Boyd, J.H.; Hancock, R.E.W. An endotoxin tolerance signature predicts sepsis and organ dysfunction at initial clinical presentation. EBioMedicine 2014, 1, 64-71. [CrossRef] [PubMed] 
64. McClure, C.; Brudecki, L.; Ferguson, D.A.; Yao, Z.Q.; Moorman, J.P.; McCall, C.E.; Gazzar, M. El microRNA 21 (miR-21) and miR-181b couple with NFI-A to generate myeloid-derived suppressor cells and promote immunosuppression in late sepsis. Infect. Immun. 2014, 82, 3816-3825. [CrossRef] [PubMed]

65. Belopolskaya, O.B.; Smelaya, T.V. Clinical associations of host genetic variations in the genes of cytokines in critically ill patients. Clin. Exp. Immunol. 2015, 180, 531-541. [CrossRef] [PubMed]

66. Jacobi, J. Pathophysiology of sepsis. Am. J. Heal Pharm. 2002, 59, 1435-1444. [CrossRef]

67. Puskarich, M.; Shapiro, N.; Trzeciak, S. Plasma levels of mitochondrial DNA in patients presenting to the emergency department with sepsis. Shock 2012, 38, 337-340. [CrossRef] [PubMed]

68. Fejes, Z.; Szilágyi, B.; Kappelmayer, J.; Ifj Nagy, B. Alteration in the expression of platelet microRNAs in diseases with abnormal platelet activation. Orv. Hetil. 2018, 159, 1962-1970. [CrossRef]

69. Hassan, F.I.; Didari, T.; Khan, F.; Mojtahedzadeh, M.; Abdollahi, M. The role of epigenetic alterations involved in sepsis: An overview. Curr. Pharm. Des. 2018, 24, 2862-2869. [CrossRef]

70. Ehrnthaller, C.; Flierl, M.; Perl, M.; Denk, S.; Unnewehr, H.; Ward, P.A.; Radermacher, P.; Ignatius, A.; Gebhard, F.; Chinnaiyan, A.; et al. The molecular fingerprint of lung inflammation after blunt chest trauma. Eur. J. Med. Res. 2015, 20, 70. [CrossRef]

71. Zhai, R.; Gong, M.N.; Zhou, W.; Thompson, T.B.; Kraft, P.; Su, L.; Christiani, D.C. Genotypes and haplotypes of the VEGF gene are associated with higher mortality and lower VEGF plasma levels in patients with ARDS. Thorax 2007, 62, 718-722. [CrossRef] [PubMed]

72. Medford, A.R.; Millar, A.B. Vascular endothelial growth factor (VEGF) in acute lung injury (ALI) and acute respiratory distress syndrome (ARDS): Paradox or paradigm? Thorax 2006, 61, 621-626. [CrossRef]

73. Duan, Q.; Chen, C.; Yang, L.; Li, N.; Gong, W.; Li, S.; Wang, D.W. MicroRNA regulation of unfolded protein response transcription factor XBP1 in the progression of cardiac hypertrophy and heart failure in vivo. J. Transl. Med. 2015, 13, 363. [CrossRef] [PubMed]

74. Blass, S.C.; Goost, H.; Tolba, R.H.; Stoffel-Wagner, B.; Kabir, K.; Burger, C.; Stehle, P.; Ellinger, S. Time to wound closure in trauma patients with disorders in wound healing is shortened by supplements containing antioxidant micronutrients and glutamine: A. PRCT. Clin. Nutr. 2012, 31, 469-475. [CrossRef] [PubMed]

75. Yehya, N.; Yerrapureddy, A.; Tobias, J.; Margulies, S.S. MicroRNA modulate alveolar epithelial response to cyclic stretch. BMC Genom. 2012, 13, 154. [CrossRef]

76. Kulshreshtha, R.; Ferracin, M.; Wojcik, S.E.; Garzon, R.; Alder, H.; Agosto-Perez, F.J.; Davuluri, R.; Liu, C.-G.; Croce, C.M.; Negrini, M.; et al. A microRNA signature of hypoxia. Mol. Cell Biol. 2007, 27, 1859-1867. [CrossRef]

77. Moschos, S.A.; Williams, A.E.; Perry, M.M.; Birrell, M.A.; Belvisi, M.G.; Lindsay, M.A. Expression profiling in vivo demonstrates rapid changes in lung microRNA levels following lipopolysaccharide-induced inflammation but not in the anti-inflammatory action of glucocorticoids. BMC Genom. 2007, 8, 240. [CrossRef]

78. Tacke, F.; Roderburg, C.; Benz, F.; Cardenas, D.V.; Luedde, M.; Hippe, H.-J.; Frey, N.; Vucur, M.; Gautheron, J.; Koch, A.; et al. Levels of circulating miR-133a are elevated in sepsis and predict mortality in critically Ill patients. Crit. Care Med. 2014, 42, 1096-1104. [CrossRef]

79. Wang, X.; Huang, W.; Yang, Y.; Wang, Y.; Peng, T.; Chang, J.; Caldwell, C.C.; Zingarelli, B.; Fan, G. Biochimica et biophysica acta loss of duplexmiR-223 (5p and $3 p$ ) aggravates myocardial depression and mortality in polymicrobial sepsis. BBA Mol. Basis Dis. 2014, 1842, 701-711. [CrossRef]

80. Shao, Y.; Li, J.; Cai, Y.; Xie, Y.; Ma, G.; Li, Y.; Chen, Y.; Liu, G.; Zhao, B.; Cui, L.; et al. The functional polymorphisms of miR-146a are associated with susceptibility to severe sepsis in the Chinese population. Mediat. Inflamm. 2014, 2014. [CrossRef]

81. Søndergaard, E.S.; Alamili, M.; Coskun, M.; Gögenur, I. MicroRNA's are novel biomarkers in sepsis-A systematic review. Trends Anaesth. Crit. Care 2015, 5, 151-156. [CrossRef]

82. Roderburg, C.; Luedde, M.; Vargas Cardenas, D.; Vucur, M.; Scholten, D.; Frey, N.; Koch, A.; Trautwein, C.; Tacke, F.; Luedde, T. Circulating microRNA-150 serum levels predict survival in patients with critical illness and sepsis. PLoS ONE 2013, 8, e54612. [CrossRef]

83. La Rosa, A.H.; Acker, M.; Swain, S.; Manoharan, M. The role of epigenetics in kidney malignancies. Cent European. J. Urol. 2015, 68, 157-164. [CrossRef] 
84. Xu, S.; Zhang, R.; Niu, J.; Cui, D.; Xie, B.; Zhang, B. Oxidative stress mediated-alterations of the microRNA expression profile in mouse hippocampal neurons. Int. J. Mol. Sci. 2012, 13, 16945-16960. [CrossRef] [PubMed]

85. Yao, L.; Liu, Z.; Zhu, J.; Li, B.; Chai, C.; Tian, Y. Clinical evaluation of circulating microRNA-25 level change in sepsis and its potential relationship with oxidative stress. Int. J. Clin. Exp. Pathol. 2015, 8, 7675-7684. [PubMed]

86. Rodrigues, C.E.; Capcha, J.M.C.; De Bragança, A.C.; Sanches, T.R.; Gouveia, P.Q.; De Oliveira, P.A.F.; Malheiros, D.M.A.C.; Volpini, R.A.; Santinho, M.A.R.; Santana, B.A.A.; et al. Human umbilical cord-derived mesenchymal stromal cells protect against premature renal senescence resulting from oxidative stress in rats with acute kidney injury. Stem Cell Res. Ther. 2017, 8, 19. [CrossRef] [PubMed]

87. Fredriksson, K.; Tjäder, I.; Keller, P.; Petrovic, N.; Ahlman, B.; Schéele, C.; Wernerman, J.; Timmons, J.A.; Rooyackers, O. Dysregulation of mitochondrial dynamics and the muscle transcriptome in ICU patients suffering from sepsis induced multiple organ failure. PLOS ONE 2008, 11, e3686. [CrossRef]

88. Huang, C.; Xiao, X.; Chintagari, N.R.; Breshears, M.; Wang, Y.; Liu, L. MicroRNA and mRNA expression profiling in rat acute respiratory distress syndrome. BMC Med. Genom. 2014, 7, 46. [CrossRef]

89. Bedreag, O.H.; Rogobete, A.F.; Dumache, R.; Sarandan, M.; Cradigati, A.C.; Papurica, M.; Craciunescu, M.C.; Popa, D.M.; Luca, L.; Nartita, R.; et al. Use of circulating microRNAs as biomarkers in critically ill polytrauma patients. Biomarkers Genom. Med. 2015, 7, 131-138. [CrossRef]

90. Benz, F.; Roy, S.; Traukwein, C.; Roderburg, C.; Luedde, T. Circulating microRNAs as biomarkers for sepsis. Int. J. Mol. Sci. 2016, 17, 78. [CrossRef]

91. Huang, J.; Sun, Z.; Yan, W.; Zhu, Y.; Lin, Y.; Chen, J.; Shen, B.; Wang, J. Identfifcation of microRNAs as sepsis biomarkers based on MiRNA regulatory network analysis. Biomed. Res. Int. 2014, 2014, 594350. [PubMed]

92. Dumache, R.; Rogobete, A.F.; Bedreag, O.H.; Sarandan, M.; Cradigati, A.C.; Papurica, M.; Dumbuleu, C.M.; Nartita, R.; Sandesc, D. Use of miRNAs as biomarkers in sepsis. Anal. Cell. Pathol. 2015, 2015, 186716. [CrossRef]

93. Sun, Z.; Zhang, Q.; Cui, X.; Yang, J.; Zhang, B.; Song, G. Differential expression of miRNA and its role in sepsis. Pediatrics 2018, 142. [CrossRef]

94. Ansari, M.; Gupta, P. Nex-Gen biomarkers-A genetic model of sepsis. Biomark. J. 2016, 2, 8. [CrossRef]

95. Vasilescu, C.; Dragomir, M.; Tanase, M.; Giza, D.; Purnichescu-Purtan, R.; Chen, M.; Yeung, S.C.-J.; Calin, G.A. Circulating miRNAs in sepsis-A network under attack: An in silico perdiction of the potential existance of microRNAs sponges in sepsis. PLoS ONE 2017, 12, e01833334. [CrossRef] [PubMed]

96. Puskarich, M.A.; Nandi, U.; Shapiro, N.I.; Trzeciak, S.; Kline, J.A.; Jones, A.E. Detection of microRNAs in patients with sepsis. J. Acute Dis. 2015, 4, 101-106. [CrossRef]

97. Weber, J.A.; Baxter, D.H.; Zhang, S.; Huang, D.Y.; Huang, K.H.; Lee, M.J.; Galas, D.J.; Wang, K. The microRNA spectrum in 12 body fluids. Clin. Chem. 2010, 56, 1733-1741. [CrossRef]

98. Díaz-Prado, S.; Cicione, C.; Muiños-López, E.; Hermida-Gómez, T.; Oreiro, N.; Fernández-López, C.; Blanco, F.J. Characterization of microRNA expression profiles in normal and osteoarthritic human chondrocytes. $B M C$ Musculoskelet. Disord. 2012, 13, 144. [CrossRef]

99. Campomenosi, P.; Gini, E.; Noonan, D.M.; Poli, A.; D'Antona, P.; Rotolo, N.; Dominioni, L.; Imperatori, A. A comparison between quantitative PCR and droplet digital PCR technologies for circulating microRNA quantification in human lung cancer. BMC Biotechnol. 2016, 16, 60. [CrossRef]

100. Warburton, A.; Savage, A.L.; Myers, P.; Peeney, D.; Bubb, V.J.; Quinn, J.P. Molecular signatures of mood stabilisers highlight the role of the transcription factor REST/NRSF. J. Affect. Disord. 2014, 172, 63-73. [CrossRef]

101. Inchley, C.S.; Sonerud, T.; Fjærli, H.O.; Nakstad, B. Nasal mucosal microRNA expression in children with respiratory syncytial virus infection. BMC Infect. Dis. 2015, 15, 150. [CrossRef] [PubMed]

102. Dong, J.; Liu, Y.; Liao, W.; Liu, R.; Shi, P.; Wang, L. MiRNA-223 is a potential diagnostic and prognostic marker for osteosarcoma. J. Bone Oncol. 2016, 5, 74-79. [CrossRef] [PubMed]

103. Hu, Z.; Chen, X.; Zhao, Y.; Tian, T.; Jin, G.; Shu, Y.; Chen, Y.; Xu, L.; Zen, K.; Zhang, C.; et al. Serum microRNA signatures identified in a genome-wide serum microRNA expression profiling predict survival of non-small-cell lung cancer. J. Clin. Oncol. 2010, 28, 1721-1726. [CrossRef] [PubMed] 
104. Pandey, A.C.; Semon, J.A.; Kaushal, D.; O’Sullivan, R.P.; Glowacki, J.; Gimble, J.M.; Bunnell, B.A. MicroRNA profiling reveals age-dependent differential expression of nuclear factor kappaB and mitogen-activated protein kinase in adipose and bone marrow-derived human mesenchymal stem cells 928. Stem Cell Res. Ther. 2011, 2, 49. [CrossRef] [PubMed]

105. Haider, B.A.; Baras, A.S.; McCall, M.N.; Hertel, J.A.; Cornish, T.C.; Halushka, M.K. A critical evaluation of microRNA biomarkers in non-neoplastic disease. PLoS ONE 2014, 9. [CrossRef] [PubMed]

106. Zheng, D.; Yu, Y.; Li, M.; Wang, G.; Chen, R.; Fan, G.C.; Martin, C.; Xiong, S.; Peng, T. Inhibition of microRNA 195 prevents apoptosis and multiple-organ injury in mouse models of sepsis. J. Infect. Dis. 2016, 213, 1661-1670. [CrossRef] [PubMed]

107. Fang, C.; Zhao, J.; Li, J.; Qian, J.; Liu, X.; Sun, Q.; Liu, W.; Tian, Y.; Ji, A.; Wu, H.; et al. Massively parallel sequencing of microRNA in bloodstains and evaluation of environmental influences on miRNA candidates using realtime polymerase chain reaction. Forensic. Sci. Int. Genet. 2018, 38, 32-38. [CrossRef]

108. Tian, F.; Yuan, C.; Hu, L.; Shan, S. MicroRNA-93 inhibits inflammatory responses and cell apoptosis after cerebral ischemia reperfusion by targeting interleukin-1 receptor-associated kinase 4. Exp. Ther. Med. 2017, 14, $2903-2910$. [CrossRef]

109. Qiu, J.; Zhou, X.; Zhou, X.; Cheng, R.; Liu, H.; Li, Y. Neuroprotective effects of microRNA-210 on hypoxic-ischemic encephalopathy. BioMed Res. Int. 2013, 2013, 350419. [CrossRef]

110. Hara, N.; Kikuchi, M.; Miyashita, A.; Hatsuta, H.; Saito, Y.; Kasuga, K.; Murayama, S.; Ikeuchi, T.; Kuwano, R. Serum microRNA miR-501-3p as a potential biomarker related to the progression of Alzheimer's disease. Acta Neuropathol. Commun. 2017, 5, 10. [CrossRef]

111. Xiao, B.; Liu, H.; Gu, Z. Expression of microRNA-133 inhibits epithelial-Mesenchymal transition in lung cancer cells by directly targeting FOXQ1. Arch. Bronconeumol. 2016, 52, 505-511. [CrossRef] [PubMed]

112. Liz, J.; Esteller, M. IncRNAs and microRNAs with a role in cancer development. Biochim. Biophys. Acta Gene Regul. Mech. 2016, 1859, 169-176. [CrossRef] [PubMed]

113. Bera, A.; Ghosh-Choudhury, N.; Dey, N.; Das, F.; Kasinath, B.S.; Abboud, H.E.; Ghosh, G. NF-kB-mediated cyclin D1 expression by microRNA-21 in fluences renal cancer cell proliferation. Cell Signal. 2013, 25, 2575-2586. [CrossRef] [PubMed]

114. Huang, J.; Liu, J.; Chen-Xiao, K.; Zhang, X.; Lee, W.N.P.; Go, V.L.W.; Xiao, G.G. Advance in microRNA as a potential biomarker for early detection of pancreatic cancer. Biomark. Res. 2016, 4, 20. [CrossRef] [PubMed]

115. Li, S.; Liang, Z.; Xu, L.; Zou, F. MicroRNA-21: A ubiquitously expressed pro-survival factor in cancer and other diseases. Mol. Cell. Biochem. 2012, 360, 147-158. [CrossRef] [PubMed]

116. Zhou, X.; Su, S.; Li, S.; Pang, X.; Chen, C.; Li, J. MicroRNA-146a down-regulation correlates with neuroprotection and targets pro-apoptotic genes in cerebral ischemic injury in vitro. Brain Res. 2016, 1648, 136-143. [CrossRef] [PubMed]

117. Dumache, R.; Ciocan, V.; Muresan, C.; Enache, A. Molecular DNA analysis in forensic identification. Clin. Lab. 2016, 62, 245-248. [CrossRef] [PubMed]

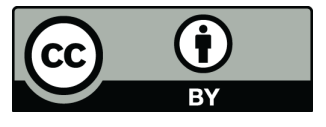

(C) 2018 by the authors. Licensee MDPI, Basel, Switzerland. This article is an open access article distributed under the terms and conditions of the Creative Commons Attribution (CC BY) license (http:/ / creativecommons.org/licenses/by/4.0/). 